\title{
Sperimentazione di una procedura per la creazione di un atlante digitale per la documentazione dei soffitti lignei dipinti di Sicilia
}

\author{
Fabrizio Agnello \\ Mirco Cannella
}

\section{Abstract}

In Sicilia, tra XII e XVI secolo, sono stati realizzati numerosi soffitti lignei dipinti, ubicati in chiese e in palazzi nobiliari. Le pitture che decorano i soffitti posseggono un elevato valore documentario poiché documentano l'ampiezza delle relazioni che legavano la Sicilia all'Europa e al bacino mediterraneo. II contributo illustra i risultati di una ricerca rivolta alla definizione di una procedura per la creazione di un atlante dei soffitti dipinti di Sicilia. La rappresentazione digitale consente di superare uno dei principali ostacoli allo studio, alla tutela e alla divulgazione di queste opere d'arte, owero la tradizionale dicotomia tra immagini fotografiche e disegni.

II caso studio prescelto è il soffitto che copre la sala magna dello Steri di Palermo, una residenza nobiliare del XIV secolo, oggi sede del rettorato dell'università; la prima fase dello studio ha condotto, attraverso il rilievo e la successiva fase di elaborazione, alla costruzione di un modello mesh texturizzato del soffitto.

La fase successiva è stata indirizzata alla suddivisione del modello in unità base che ne rendessero più agevole la visualizzazione; la fase conclusiva è stata dedicata allo sviluppo di un applicativo web-based che permette la visualizzazione dei modelli 3D e di ortofoto degli elementi del soffitto; dalle pagine dedicate alle ortofoto è possibile accedere un database editabile che consente l'archiviazione e l'aggiornamento di dati informativi relativi al soffitto.

Parole chiave

soffitti lignei, rilievo digitale, modelli digitali, applicazione web-based, database informativo.
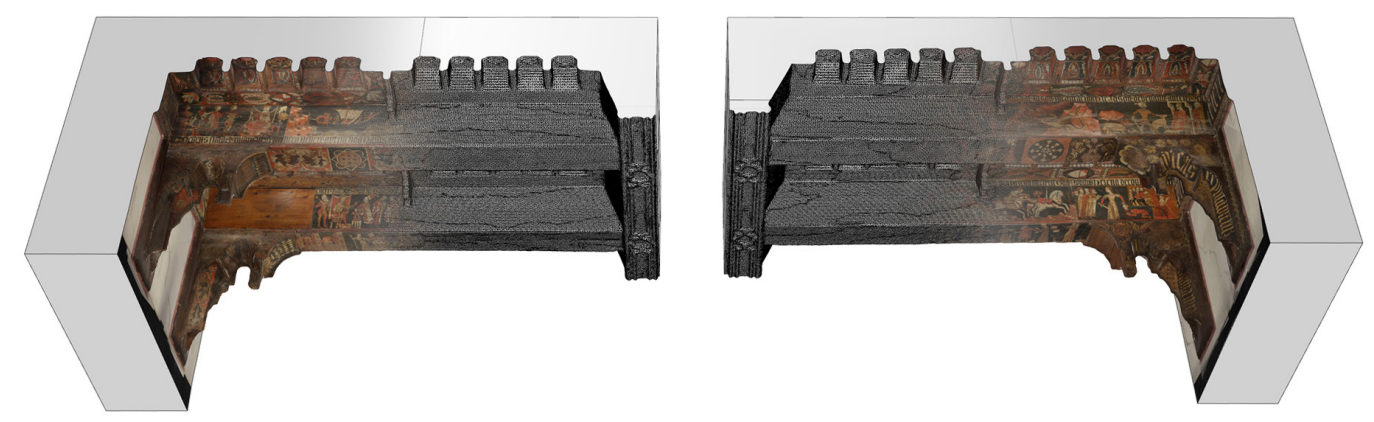


\section{Introduzione}

In Sicilia [I], tra XII e XVI secolo, sono stati realizzati numerosi soffitti lignei decorati da pitture, ubicati in chiese e in palazzi nobiliari.

I due esempi più rilevanti di questa lunga e prolifica tradizione, entrambi ubicati a Palermo, sono il soffitto che si trova nella navata centrale della Cappella Palatina nel Palazzo Reale e il soffitto che copre la grande sala al piano nobile dello Steri, sede del rettorato dell'Università. I due soffitti sono molto diversi tra loro: quello della Cappella Palatina, costruito fra il | I30 e il I 154, presenta una struttura a muqarnas che sarà replicata in numerose volte in pietra costruite a Palermo nelle sale delle residenze reali nei due secoli successivi.

II soffitto dello Steri, costruito due secoli dopo, fra il 1377 e il I 380, fissa il prototipo di una gran parte dei soffitti conosciuti, costituiti da travi con interassi molto contenuti, intervallate da cassettoni; il soffitto è decorato in ogni sua parte da pitture.

II soffitto copre interamente la grande Sala, per una estensione di 27.75*8.45m; la sua struttura è costituita da 24 travi disposte trasversalmente e direttamente incastrate ai muri longitudinali della sala (fig. I). Tali travi, di rozza fattura, sono rivestite da pannelli lignei spessi circa $3 \mathrm{~cm}$, decorati dalle pitture. Un elemento centrale di sezione trapezia attraversa longitudinalmente l'intera sala, determinando la suddivisione del soffitto in due parti, denominate $A$ e $B$ in studi precedenti. La classificazione del soffitto riporta dunque 24 travi A, 24 travi B, 25 cassettoni A e 25 B.

L'incastro fra le travi e i muri d'ambito è celato da 48 finte mensole, la cui morfologia e tecnica costruttiva richiama il soffitto della Cappella Palatina.

I cicli pittorici dello Steri sono tutti riferiti alla donna, nella sua duplice accezione di stimolo alla redenzione o causa di perdizione per l'uomo. Le pitture che decorano tali soffitti posseggono un alto valore documentario per ricostruire il contesto culturale, la circolazione di testi e apparati simbolici e la loro permanenza all'interno dell'isola e nei paesi con i quali la Sicilia intratteneva scambi culturali.

La rappresentazione digitale consente di superare la tradizionale dicotomia tra immagini fotografiche e disegni, che non ha facilitato la comprensione e la divulgazione di queste opere d'arte, caratterizzate da una da uno stretto rapporto fra il progetto pittorico e la morfologia delle superfici dipinte.

\section{Dal continuo al discreto. Segmentazione di modelli mesh}

È ben noto che le tecnologie digitali per il rilievo conducono all'acquisizione di nuvole di punti che documentano in dettaglio le superfici misurate e possono essere utilizzate per diversi scopi: I) generare modelli mesh a maglia triangolare per interpolazione automatica dei punti della nuvola; 2) disegnare elaborati grafici convenzionali o costruire modelli tridimensionali NURBS.

II progetto di opere d'arte e di architettura, in particolare nell'età pre-digitale, utilizzava prevalentemente elementi discreti connessi da spigoli e vertici.

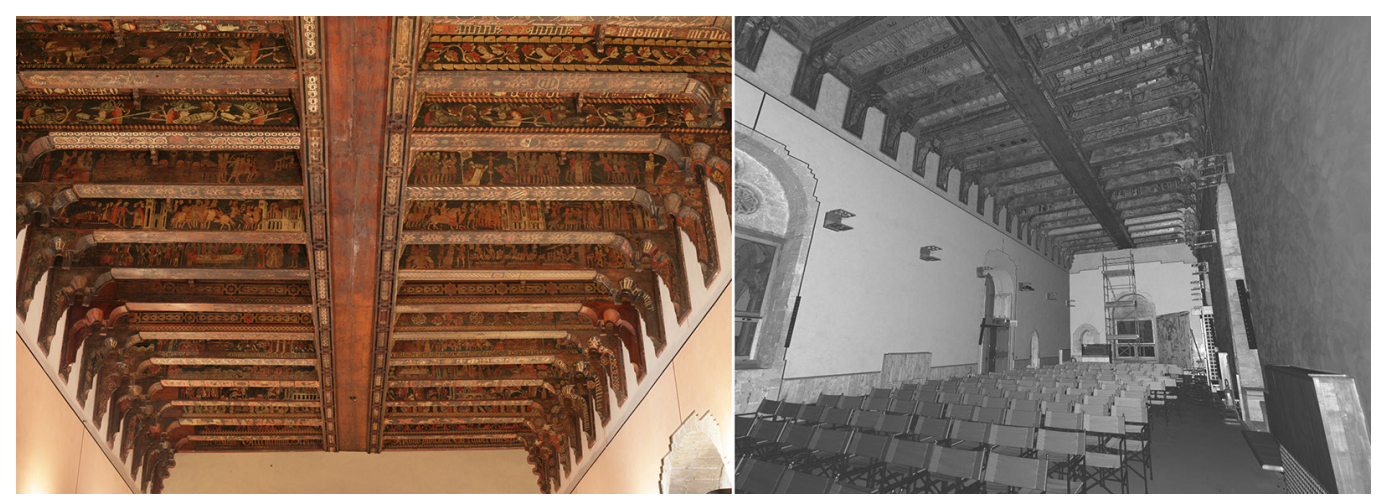


Le nuvole di punti e le mesh sono rappresentazioni 'continue', particolarmente efficaci nella documentazione di forme libere, come ad esempio l'orografia o la statuaria. Le nuvole di punti e le mesh sono ampiamente utilizzate per la rappresentazione di manufatti geometrici, ma non possono documentare le soluzioni di continuità che caratterizzano un edificio o un soffitto; angoli, spigoli e vertici non possono essere rappresentati nelle nuvole di punti e nelle mesh, poiché sono astrazioni geometriche.

Per questo motivo la produzione di disegni e modelli NURBS da nuvole di punti è tutt'altro che automatica e richiede operatori capaci di interpretare la struttura geometrica degli artefatti rilevati.

La segmentazione è il processo che conduce alla ricostruzione del percorso progettuale ed è pertanto particolarmente importante nei casi in cui gli aspetti geometrici sono una caratteristica rilevante degli oggetti rilevati. Diversi studi hanno affrontato le questioni legate alla segmentazione automatica e all'interpretazione semantica di mesh e nuvole di punti, attraverso il riconoscimento delle caratteristiche morfologiche di oggetti 3D archiviati in un database.

Gli strumenti proposti offrono un supporto a quegli operatori che gestiscono dati 3D relativi a opere d'arte e di architettura in assenza di una specifica formazione alla loro interpretazione, ma tali strumenti sono ancora in fase di sviluppo e non sempre gli esiti soddisfano le aspettative.

II processo di segmentazione è difficilmente applicabile alla rappresentazione di un soffitto dipinto d'epoca, particolarmente nei casi in cui la geometria della superficie dipinta ha subito assestamenti e deformazione che rendono impraticabile l'estrazione di una superficie NURBS che approssimi la superficie reale.

In queste circostanze le mesh generate da un rilievo laser scanning o fotogrammetrico sono da preferire perché possono essere texturizzate accuratamente con procedure fotogrammetriche; se il modello fotogrammetrico è riferito allo stesso sistema di coordinate usato dalla nuvola di punti acquisita con lo scanner, le mesh estratte da questa nuvola possono essere collegate al progetto fotogrammetrico e quindi texturizzate.

In questo studio la suddivisione della mesh texturizzata non è assimilabile a una segmentazione, poiché non mira alla rappresentazione degli aspetti geometrici o costruttivi del soffitto. La suddivisione è semplicemente finalizzata a semplificare la visualizzazione della mesh $3 \mathrm{D}$ texturizzata nell'applicazione web-based che sarà descritta più avanti.

\section{II rilievo del soffitto}

Il rilievo del soffitto ligneo dello Steri è stato condotto con tecniche laser scanning e fotogrammetriche.

In una fase iniziale, prima dell'allestimento del cantiere di restauro, le scansioni sono state acquisite dal piano di calpestio; le successive scansioni sono state acquisite dal ponteggio allestito per i lavori di restauro.

La possibilità di eseguire le scansioni da quote differenti ha permesso di chiudere la maggior parte delle lacune presenti nelle scansioni acquisite dal piano di calpestio della sala; le uniche lacune corrispondono alle facce verticali delle travi poste alle estremità della sala e rivolte verso le pareti.

Per colmare tali lacune sono state inserite superfici piane NURBS; la successiva conversione di tali superfici in nuvole di punti, attraverso un processo di campionatura, ha permesso di ripristinare la continuità fra la nuvola di punti del soffitto e quella della sala.

L'elaborazione delle nuvole di punti acquisite con lo scanner ha seguito una procedura ormai consolidata: le nuvole di punti sono state orientate e quindi campionate per ridurre i punti ridondanti; al fine di utilizzare le nuvole di punti per la costruzione di un modello mesh si è proceduto al calcolo delle normali dei punti, ovvero dei vettori orientati verso il punto di scansione.

Il calcolo delle normali ha permesso di costruire un modello mesh dell'intero intradosso del soffitto ligneo attraverso specifici plug-in [2], basati sugli algoritmi di distribuzione di punti di 
Poisson (fig. 2). II modello mesh ottenuto è caratterizzato da un ottimale rapporto fra il numero complessivo dei triangoli e il livello di dettaglio, nonché da un efficace contenimento del rumore presente nelle nuvole di punti.

Il rilievo fotogrammetrico è stato finalizzato esclusivamente al texturing dei modelli mesh e alla produzione delle ortofoto dei singoli pannelli lignei e dei mensoloni.

II rilievo è stato concepito come l'insieme di più distinti progetti fotogrammetrici dedicati a ciascuna campata. Le foto sono state acquisite dalla quota del ponteggio, con una camera mirrorless posizionata su treppiede e un sistema di illuminazione allestito ad hoc, con pannelli a led retti da un secondo treppiede. La possibilità di svincolare la fonte di luce dalla posizione della camera, ha permesso di tenere costantemente sotto controllo la riflessione speculare indotta dalle vernici lucide applicate a protezione delle pitture.

Ogni singolo progetto fotogrammetrico è stato riferito al medesimo sistema di coordinate tramite l'estrazione, dalla nuvola di punti acquisita con lo scanner, delle coordinate di punti riconoscibili nelle immagini fotografiche (fig. 3).

II risultato finale del rilievo è la creazione dei modelli 3D texturizzati delle unità base del soffitto (fig. 4).
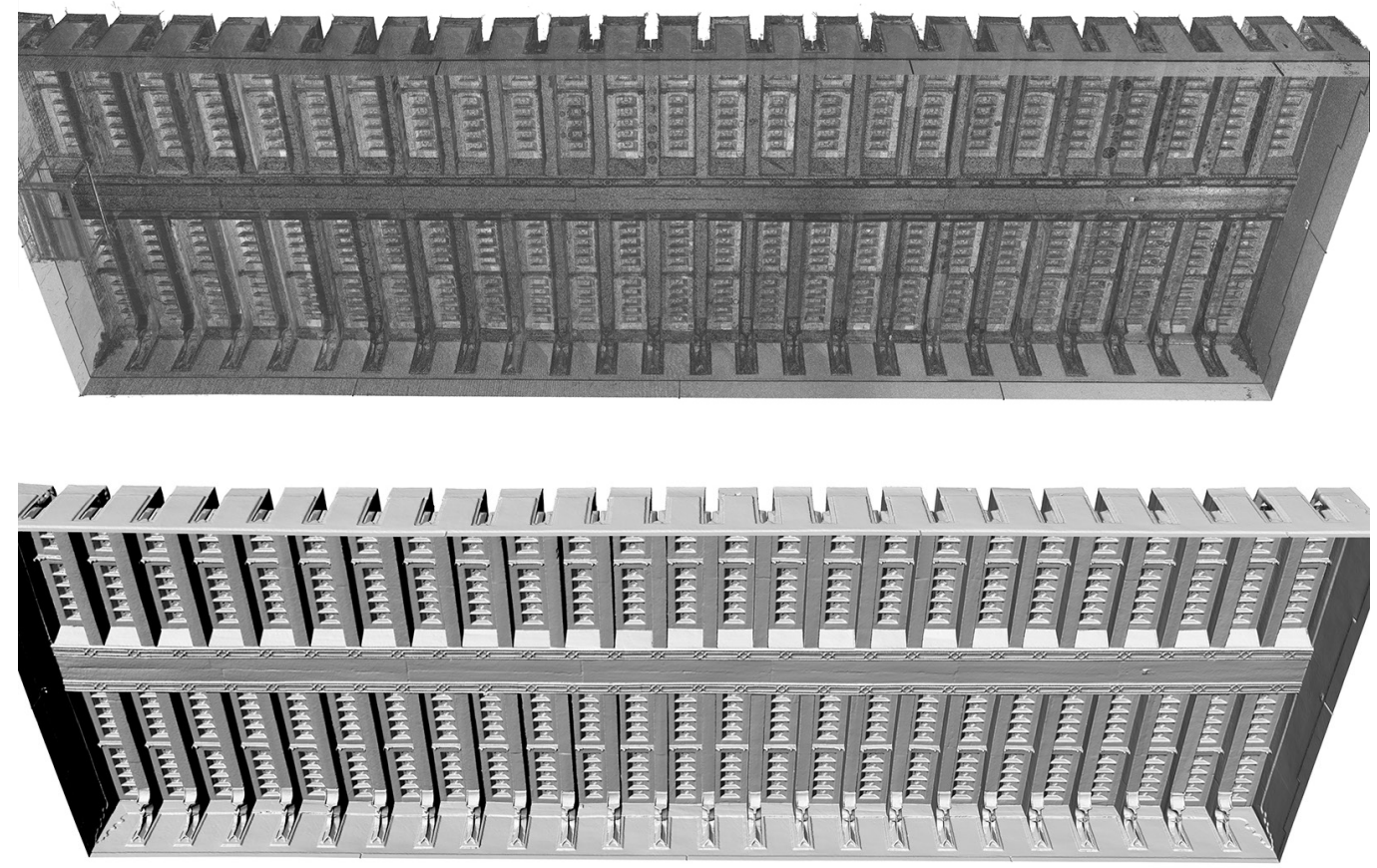

\section{Applicativo web based per la visualizzazione delle pitture}

Al fine di poter rendere il modello così creato accessibile a un'ampia utenza di studiosi e funzionari preposti alla sua tutela, non esperti nell'utilizzo di strumenti di modellazione digitale, è stata creata un'applicazione web-based che unisce elementi grafici e database informativi. Il problema principale nella visualizzazione del soffitto riguarda la sua notevole dimensione e la sua complessa morfologia, caratterizzata da un susseguirsi di pannelli verticali, orizzontali e obliqui, e da mensoloni molto articolati.

La visualizzazione dell'intero modello risulterebbe complessa e renderebbe difficile l'individuazione della posizione dei pannelli dipinti; non è un caso che gli studi fin qui condotti dagli storici dell'arte si siano lungamente incentrati sul problema della classificazione delle travi e dei cassettoni.

Si è dunque scelto di suddividere il modello in unità base ridondanti, tali cioè che alcuni elementi si ripetessero in due unità adiacenti per garantire la percezione della continuità dei cicli pittorici. 
Fig. 3. Punti utilizzati per riferire il modello fotogrammetrico al sistema di coordinate delle scansioni laser.

Fig. 4. Texturing fotogrammetrico del modello mesh.
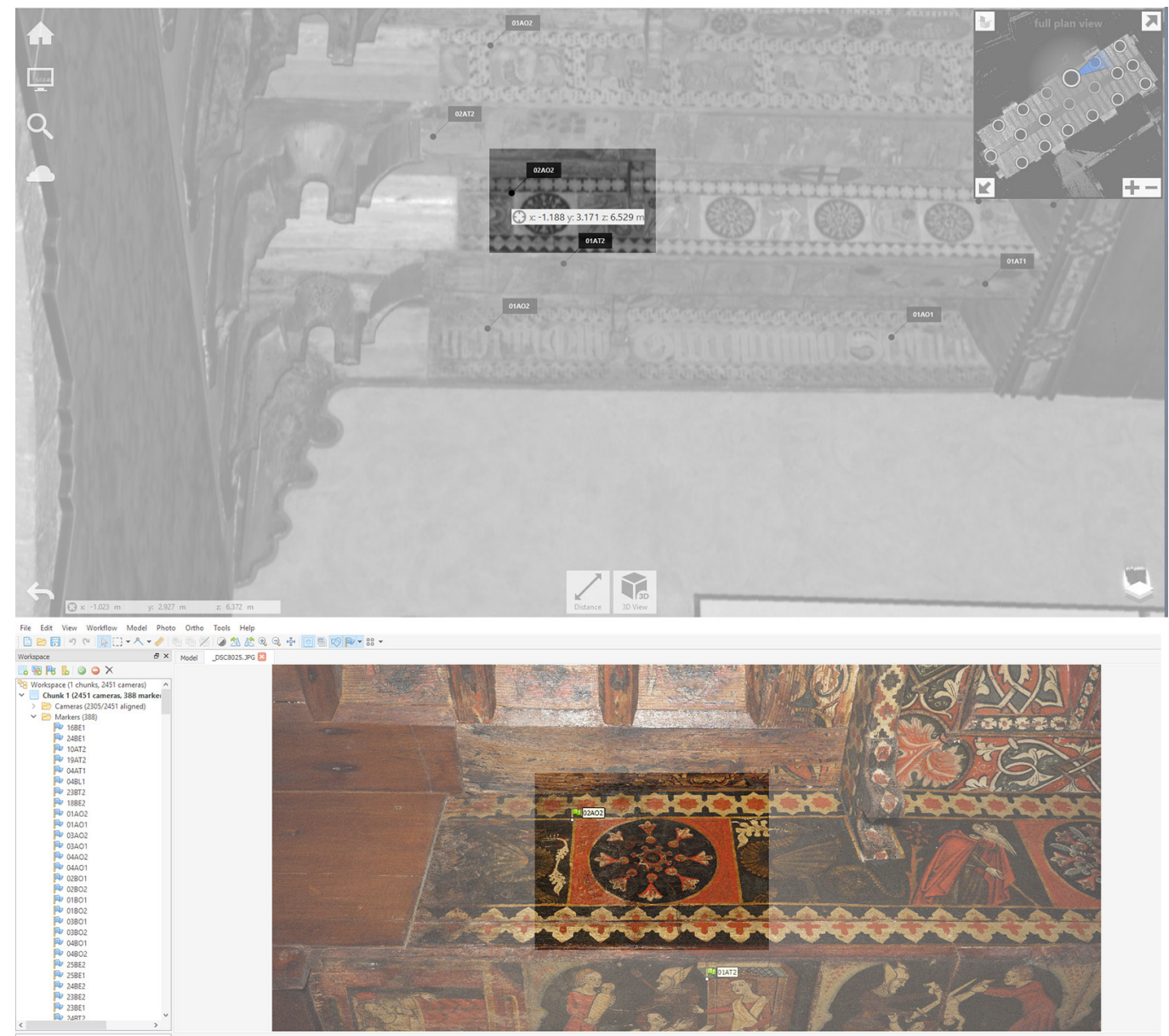

re.......

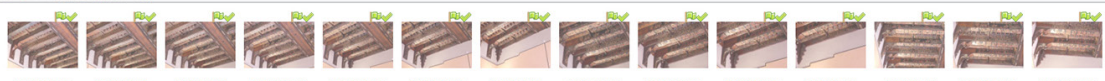

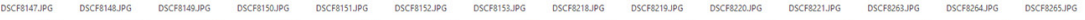

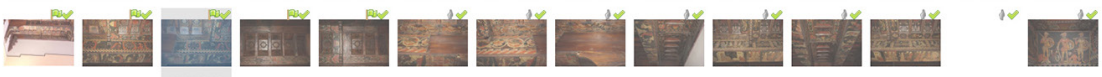
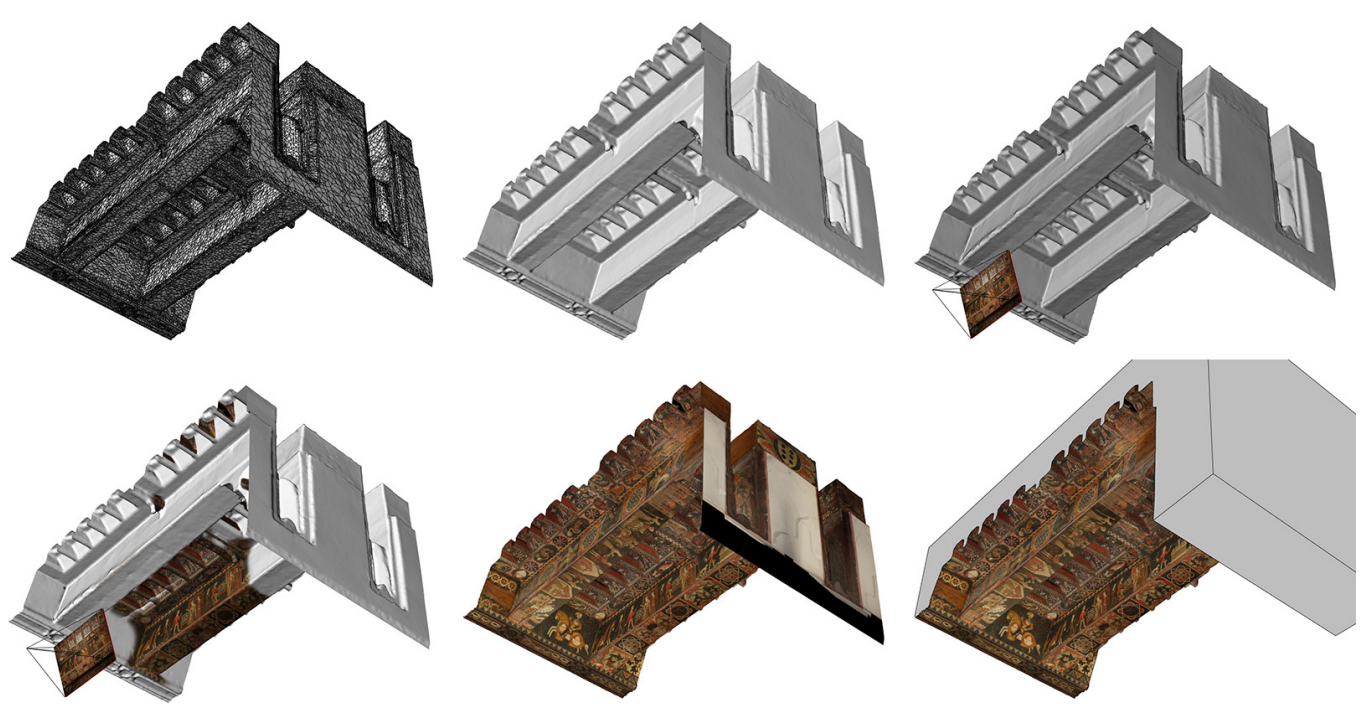
Fig. 5. Ortofoto nadirale del soffitto in toni di dell'unità base selezionata.

Fig. 6. L'immagine mostra il criterio alfanumerico usato per l'identificazione degli elementi e la sovrapposizione di due unità base adiacenti, corrispondente a una trave che compare in entrambe le unità

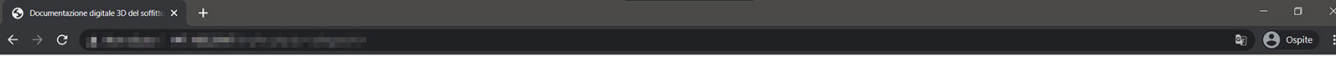

Documentazione generale

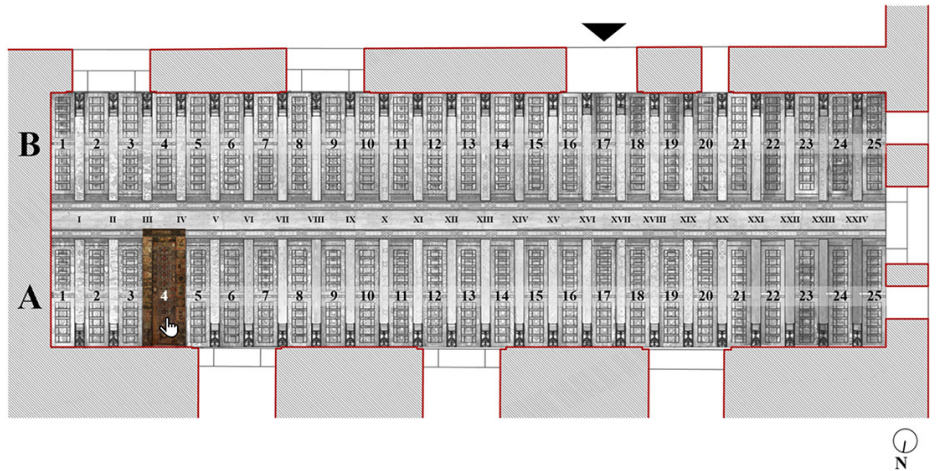

Le unità base isolano porzioni del modello che vanno dalla parete all'elemento centrale longitudinale, con il cassettone e le due travi che lo delimitano, riportate nella loro interezza; tale criterio assegna alla trave il ruolo di elemento di collegamento fra due unità consecutive.

Al fine di definire il limite di ciascuna unità, si è provveduto a costruire superfici piane che definiscono un volume di chiusura astratto, che trascura l'effettiva configurazione dell'estradosso del soffitto per dare maggior risalto alle pitture.

L'applicazione web based è stata progettata per consentire: I) la navigazione dei modelli 3D delle unità base; 2 ) la visualizzazione delle ortofoto ad alta risoluzione delle pitture dei pannelli e dei mensoloni; 3) il collegamento alle ortofoto di elementi di un database multimediale implementabile.

Al fine di semplificare l'accesso alla visualizzazione del modello, la homepage conduce immediatamente a una pagina che contiene l'ortofoto nadirale in toni di grigi dell'intero soffitto, inserita all'interno di una pianta schematica della sala (fig. 5).
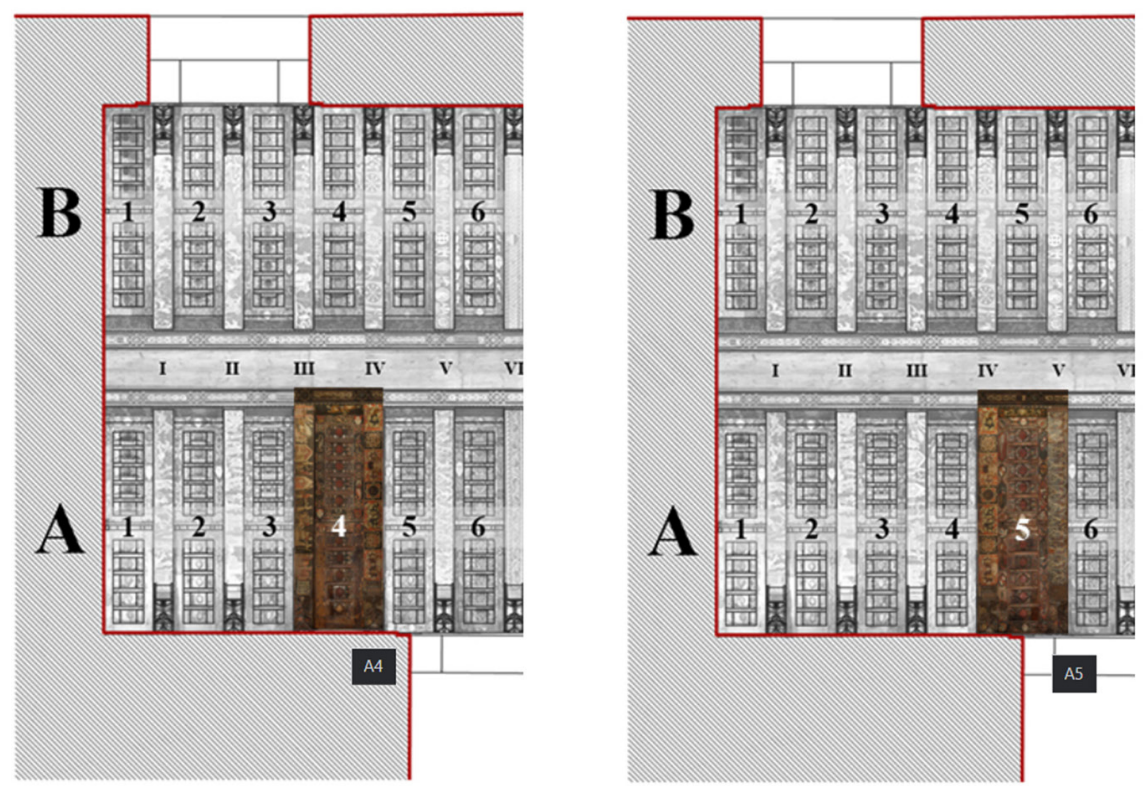


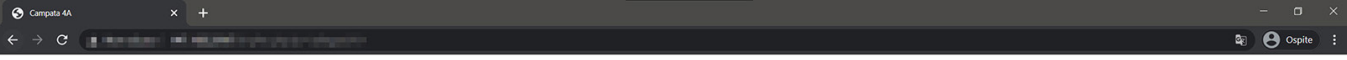

Campata $4 \mathrm{~A}$

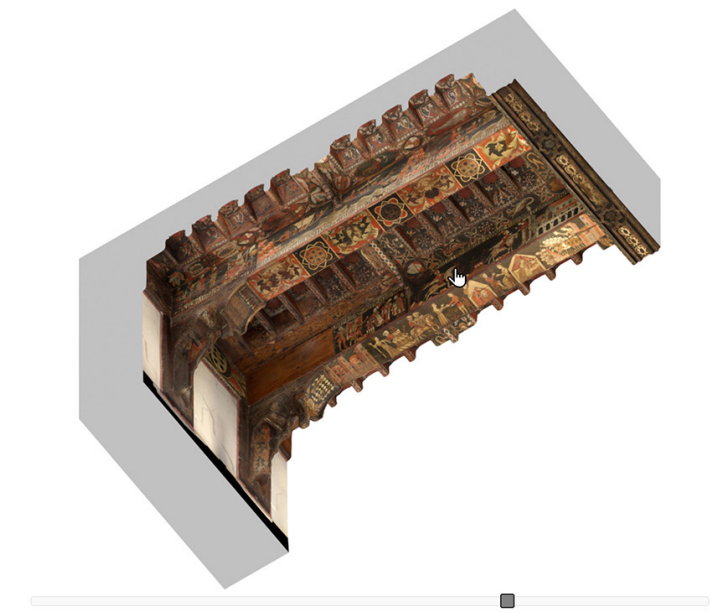

Le campate sono contrassegnate da numeri arabi, mentre i numeri romani scandiscono le 24 travi; le lettere A e B, contraddistinguono le due parti individuate dall'elemento centrale longitudinale. Al passaggio del cursore del mouse, o al tocco sui sistemi touch, la porzione di ortofoto riconducibile all'unità base si colora, mostrando l'ortofoto in modalità RGB, suggerendo così la possibilità di una più dettagliata visualizzazione dell'elemento (fig. 6).

La selezione dell'unità sull'ortofoto aprirà un'ulteriore pagina caratterizzata da una vista assonometrica iposcopica del modello texturizzato dell'unità, con l'indicazione del suo codice identificativo. Nella parte bassa della pagina compare uno slider, che permette, attraverso lo spostamento del cursore da sinistra a destra e viceversa, di gestire la rotazione del modello attorno al suo asse verticale. Questa soluzione consente di visualizzare tutti i pannelli lignei che concorrono alla formazione della campata (fig. 7).

In realtà, ciò che è visibile a schermo non è un vero e proprio modello, ma una sequenza di 28 viste assonometriche iposcopiche pre-renderizzate. Uno specifico applicativo javascript, infatti, consente di simulare la navigazione di un modello 3D attraverso la veloce successione delle immagini gestita dallo slider. La scelta di non usare un modello 3D, ma le sue viste, nasce dall'esigenza di rendere l'applicativo leggero e rapido nel suo caricamento e soprattutto compatibile con diverse piattaforme per dispositivi desktop e mobili.

I rendering dei singoli frame sono stati realizzati con il software Blender, attraverso la definizione di una animazione, lungo un percorso semicircolare, di una camera virtuale costantemente orientata verso il centro della campata.

La scelta di permettere l'accesso alle ortofoto direttamente dalle viste dei modelli 3D facilita l'individuazione dell'elemento desiderato e la comprensione delle relazioni di prossimità con gli altri elementi del soffitto.

A ciascuna delle 28 viste dell'unità base, sono state associate specifiche aree sensibili, corrispondenti agli elementi raffigurati nelle ortofoto; tali aree sono state definite attraverso la creazione di mappe poligonali con apposito codice html.

Le ortofoto (fig. 8), ad alta risoluzione, possono essere ingrandite e traslate per consentire la lettura dei più piccoli dettagli delle pitture; una piccola finestra pop-up, posta in alto a sinistra, aiuta l'utente a contestualizzare il dettaglio inquadrato rispetto all'intera ortofoto (fig. 9).

Dalla stessa pagina, attraverso un link posto in alto a destra, è possibile accedere al database. L'accesso è stato strutturato in due livelli: al primo livello è possibile consultare ed eventualmente effettuare il download dei documenti associati al pannello, attraverso un file manager basato su linguaggio PHP; il secondo livello, accessibile solo da parte di utenti autorizzati dal gestore del sito, consente di caricare nuovi documenti, modificare gli esistenti o cancellarli definitivamente. II database è archiviato su un server dell'Università di Palermo (fig. I0). 
Fig. 8. Pagina dedicata alla visualizzazione
dell'ortofoto di una faccia verticale di una trave.

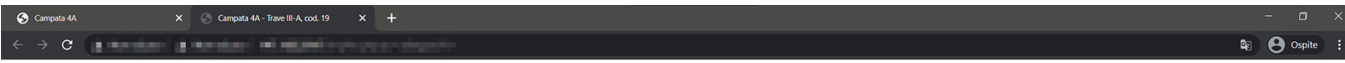

Allegati

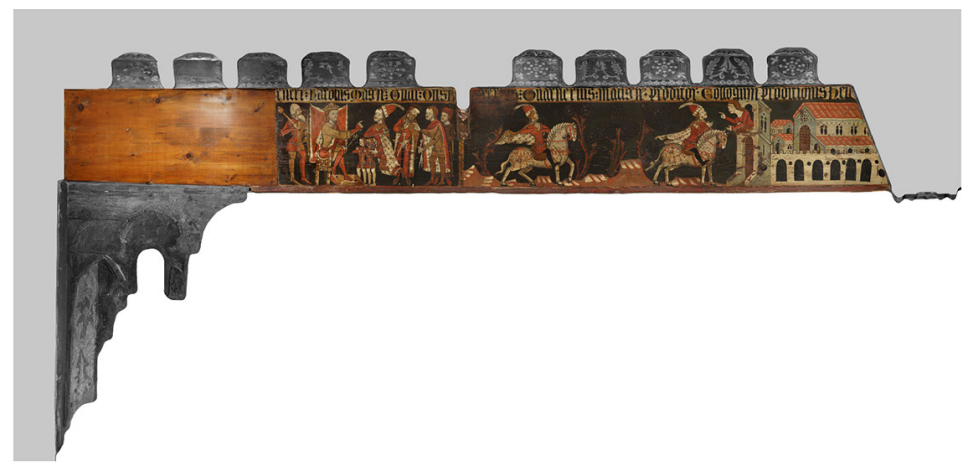

Campata 4A - Trave III-A, cod. 19

Storia di Elena di Narbona

\section{Conclusioni e prospettive di ricerca}

La ricerca ha condotto alla costruzione di un modello tridimensionale texturizzato del soffitto ligneo dipinto che copre la sala magna dello Steri di Palermo, sede del rettorato dell'Università, e allo sviluppo di un'applicazione web-based per l'archiviazione e l'aggiornamento di dati informativi legati al soffitto.

L'applicazione è stata progettata per facilitare l'accesso alle schede informative collegate e per consentire alla più ampia platea di utenti la comprensione della struttura tridimensionale del soffitto, del legame fra le pitture e il loro supporto, delle relazioni di prossimità fra i cicli pittorici.

La procedura sperimentata è estendibile agli altri soffitti dipinti presenti in Sicilia e si presta alla costruzione di un atlante digitale di questi manufatti.

Possibili ulteriori sperimentazioni potrebbero riguardare l'uso dei modelli texturizzati in applicazioni AR destinate alla fruizione in situ, con la visualizzazione real-time di contenuti informativi sui rimandi simbolici o sui soggetti raffigurati nelle pitture.
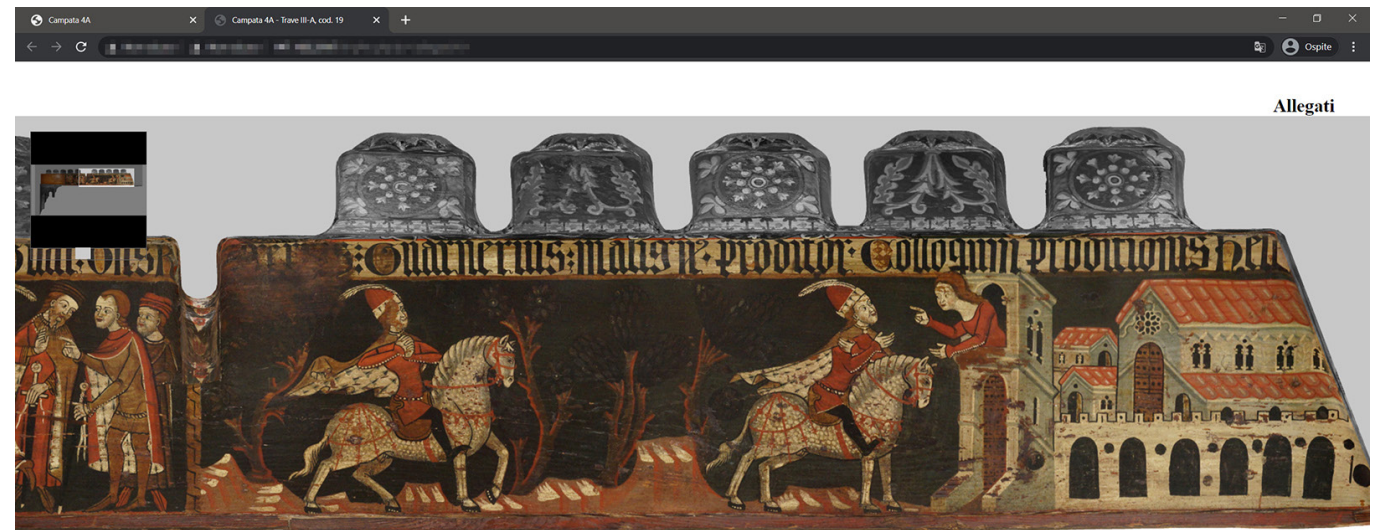

Campata 4A - Trave III-A, cod. 19

Storia di Elena di Narbona 


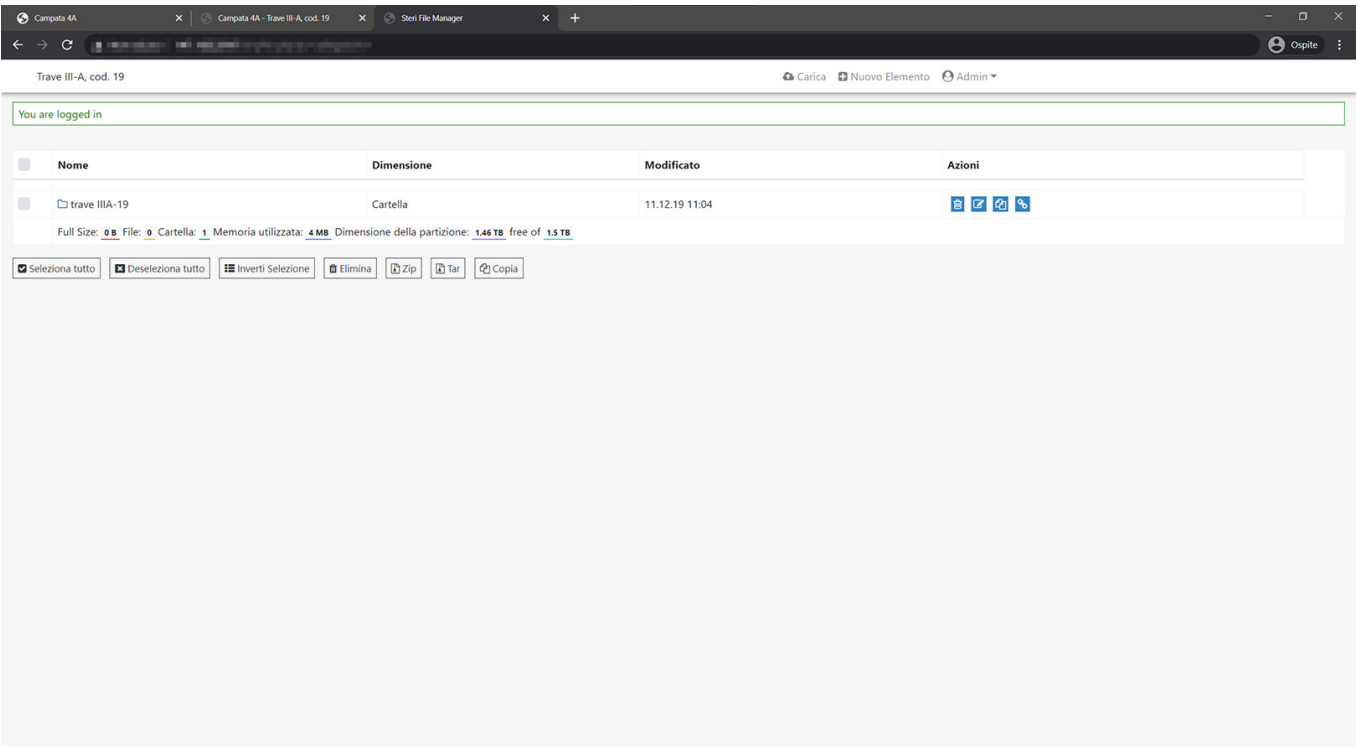

\section{Note}

[I] Contributi: Fabrizio Agnello ha curato l'introduzione e il paragrafo dedicato alla segmentazione dei modelli 3D; Mirco Cannella ha curato i paragrafi dedicati al rilievo del soffitto e allo sviluppo dell'applicazione web based. Il contributo di Mirco Cannella costituisce un prodotto della ricerca finanziata dall'Unione Europea - Fondo per lo sviluppo regionale europeo PON Aim - Ricerca e Innovazione 2014-2020.

[2] La mesh del soffitto è stata creata con il software freeware Cloud Compare.

\section{Riferimenti bibliografici}

Bologna F. (2002). Il soffitto della Sala Magna allo Steri di Palermo. Palermo: Flaccovio.

De Luca L., Bussayarat C., Stefani C.,Veron P., Florenzano M. (20I I). A semantic based platform for the digital analysis of architectural heritage. In Computers \& Graphics, 201 I, 35(2), pp. 227-241.

Gonizzi Barsanti S., Guidi G., De Luca L. (2017). Segmentation of 3d models for Cultural Heritage Structural Analysis. Some Critical Issues. In ISPRS Annals, vol. IV-2/W2, pp. I I 5- 122.

Guarnieri A., Pirotti F., Vettore A. (20 I0). Cultural heritage interactive 3D models on the web: An approach using open source and free software. In Journal of Cultural Heritage, vol. I I, Issue 3, pp. 239-364.

Lanza V. ( 1940). Saggio sui soffitti siciliani dal secolo XII al XVII. Estratto dagli Atti della Regia Accademia di Scienze, lettere ed Arti di Palermo (Serie IV, Vol. I, Parte II), Palermo.

\section{Autori}

Fabrizio Agnello, Università degli Studi di Palermo, fabrizio.agnello@unipa.it

Mirco Cannella, Università degli Studi di Palermo, mirco.cannella@unipa.it

Per citare questo capitolo: Agnello Fabrizio, Cannella Mirco (2021). Sperimentazione di una procedura per la creazione di un atlante digitale per la documentazione dei soffitti lignei dipinti di Sicilia/A Workflow for the Creation of a Digital Atlas for the Documentation of the Painted Wooden Ceilings of Sicily In Arena A Arena M Mediati D. Raff P. (a Cura di) Connettere Un disegno per annodare e tessere Lingurgei Distanze Tecnologie

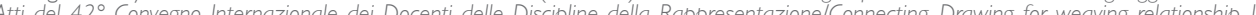
Atti del $42^{\circ}$ Co. 


\title{
A Workflow for the Creation of a Digital Atlas for the Documentation of the Painted Wooden Ceilings of Sicily
}

\author{
Fabrizio Agnello \\ Mirco Cannella
}

Abstract

In Sicily, between the 12th and the 16th century, many painted wooden ceilings were built to cover the naves of churches and the halls of noble palaces. The paintings that decorate these ceiling are precious evidences of the wide cultural connections that linked Sicily to Europe and to the Mediterranean area.

The paper reports the results of a research aiming at the development of a workflow for the creation of a digital atlas of these ceilings. Digital representation overcomes one of the main obstacle for the study, the preservation and the dissemination of these works of art, i.e. the traditional dichotomy between photographic images and drawings.

The chosen case study is the ceiling that covers the main hall of the Steri in Palermo, a I 4th century palace that today hosts the offices of the local university's rector.The first step of the study, dedicated to laser scanning and SfM photogrammetric surveying, produced a textured mesh model of the ceiling. The following step was addressed to the development of a web-based application that allows a wide range of users to visualize the 3D model of the ceiling and the orthophotos of the paintings; in order to make 3D visualization easier, the 3D textured model was subdivided in base units; the pages dedicated to the orthophotos are linked to an editable database that stores information data.

Keywords

painted wooden ceilings, digital survey, digital models, Web-based application, database.
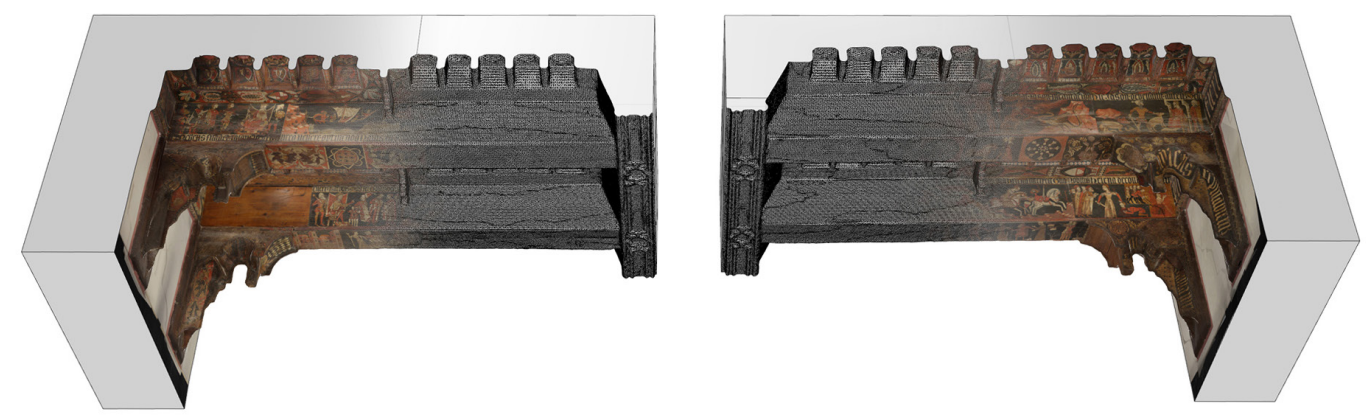


\section{Introduction}

In Sicily [I], between the I 2th and the I 6th century, many wooden ceilings decorated with paintings were built to cover the naves of churches and the halls of noble palaces.

The roots of this long and prolific tradition are two extant ceilings, both sited in Palermo: the first one covers the nave of the Palatine Chapel in the Royal Palace; the second one covers the great hall at the main floor of the Steri, a relevant I 4th century palace that today hosts the offices of the local university's rector.

The two ceilings are very different from each other: the ceiling of the Palatine Chapel, dated between I130 and I 154, features a muqarnas structure, which will be repeated in many stone vaults built in Palermo in the two following centuries, to decorate the halls of royal Norman residences.

The ceiling of the Steri, built two centuries later, between 1377 and 1380, fixes the prototype of a great part of the known ceilings, made of beams separated by short spaces covered with coffers; all the visible elements of the ceiling are painted.

The ceiling covers entirely the great hall, long $27.75 \mathrm{~m}$ and wide $8.45 \mathrm{~m}$; its structure consists of 24 transverse beams directly connected to the longitudinal walls of the hall (fig. I). These beams, roughly worked, are coated with painted panels, about $3 \mathrm{~cm}$ thick. A trapezoidal element spans the full length of the longitudinal axe of the hall, thus dividing the visible faces of the beams and the coffers in two parts, named $A$ and $B$ in previous studies. The classification of the ceiling usually accounts for 24A and 24B beams and 25A and 25B coffers.

The connection between the beams and the walls is concealed by 48 false brackets, whose morphology and construction technique echoes the ceiling of the Palatine Chapel.

The pictorial cycle of the Steri is entirely referred to the woman, in its double part of stimulus to redemption or cause of perdition for the man. The value of these paintings is more documentary than artistic, since they support the reconstruction of the primary cultural role played by Sicily at the time in the Mediterranean area; paintings reveal the circulation and permanence of symbolic references and the success of literary works that inspired the painters or their patrons.

Digital tools allow an unprecedented representation of painted ceiling, since they overcome the traditional dichotomy between photographic images and drawings, the main obstacle in the past for the dissemination, the study and the preservation of these works of art, characterized by a close relationship between the paintings and the morphology of the painted surfaces.

\section{From continuous to discrete. Segmentation of mesh models}

It is well known that the output of digital surveying is a point cloud that documents in detail the surveyed surfaces; point clouds can be used for at least two purposes: I) build triangular mesh models through automatic points' interpolation; 2) produce conventional drawings or 3D NURBS models.

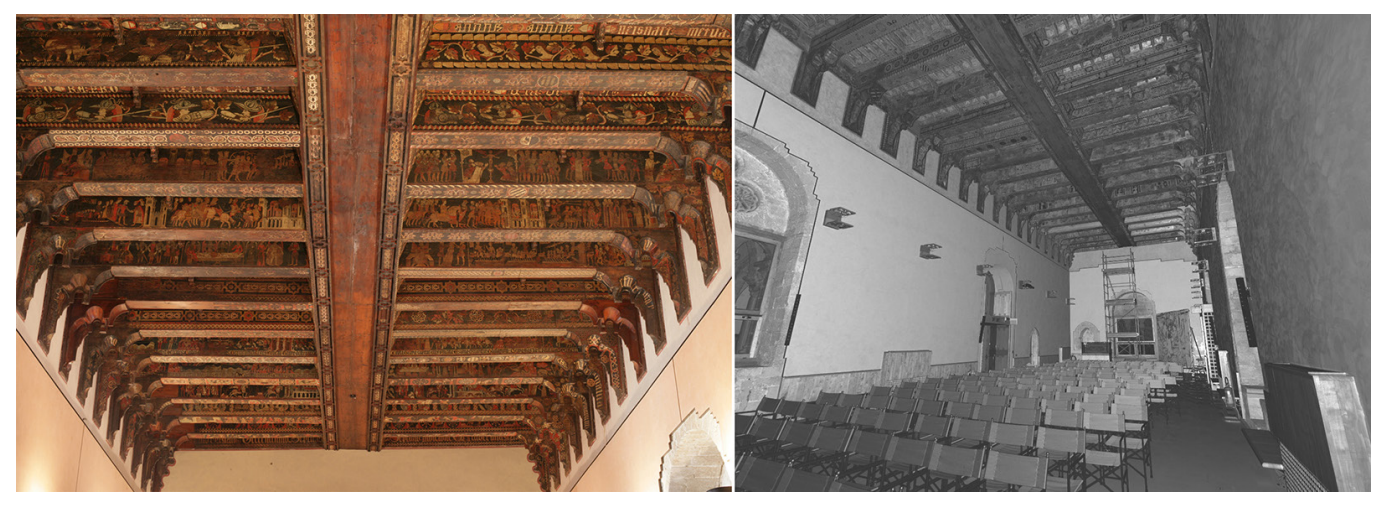


Architectural and art design, especially in the pre-digital era, mainly used well distinguished elements connected by edges and vertices.

Point clouds and meshes are continuous representations that are particularly effective in the documentation of free-form subjects, i.e. terrain or statues. Point clouds and meshes are widely used for the representation of geometric artifacts, but they cannot document the breaks that characterize a building or a ceiling; edges and vertices are not represented in point clouds and meshes, since they are geometric abstractions.

That's why the production of drawings and 3D NURBS models from point clouds is all but automatic and needs operators educated in the interpretation of the geometric structure of the surveyed artifacts.

Segmentation is the process that leads to the reconstruction of the design process and is therefore particularly relevant when geometry is a relevant feature of the surveyed object. Many studies deal with the question of automatic segmentation and semantic interpretation of point clouds and meshes, through the retrieval of geometric features by comparison with models stored in dedicated databases. The proposed tools offer a good support for operators that deal with works of art or with architecture without a specific education, but their development is still ongoing and the results do not always match the expectations.

Segmentation is impossible when the subject of representation is a dated painted ceiling, particularly when the painted surface features a complex geometry with assessments and deformations that make it impossible the extraction of a 3D NURBS model that fits the real surface.

In these circumstances the meshes automatically generated by laser scanning or photogrammetric survey are to be preferred, since they can be accurately textured with photogrammetric processes; if the photogrammetric model is referred to the same coordinate system used by the laser scanning point cloud, meshes extracted from the laser scanning point cloud can be attached to the photogrammetric project and then textured.

In this study the subdivision of the textured mesh is not a segmentation, since it does not aim at the representation of the geometric or constructive structure of the ceiling. The subdivision simply aims at providing a simpler visualization of the 3D textured mesh in the web-based application that is discussed below.

Subdivision keeps into account the links between paintings and therefore never isolates a single element, but always show those elements that are directly connected to it. This choice makes an element appear in more than an instance and thus required two different subdivisions that produced overlayed clusters.

\section{The surveying process}

Surveying was developed with laser scanning and photogrammetric techniques. At the initial stage, before the setup of the restoration yard, laser scans were taken from the ground; at a later stage further scans were taken from the scaffolding mounted for the restoration works. Scans from the scaffolding allowed to fill most of the holes that affected scans from the ground and thus the only occlusion areas resulting from the scanning process were the vertical panels of the beams at the ends of the hall, facing the walls; flat surfaces, modeled with NURBS modeling tools substituted for the occlusion areas; a sampling process was used to convert these surfaces into point clouds; these point clouds filled the occluded areas and restored the continuity between the point cloud of the ceiling and the point cloud of the hall. Laser scanning data processing followed a well-known workflow; point clouds were registered and then sampled to reduce redundant points; in order to use the point cloud for the extraction of a mesh model, the normal of points, i.e. the vectors oriented towards the scan position, were calculated.

The mesh model of the visible surfaces of the ceiling was finally calculated with plug-ins [2], based on Poisson's point distribution algorithms (fig. 2). The mesh model features an optimal combination between the number of triangles and the level of detail, as well as an effective reduction of the noise of point clouds. 
The photogrammetric survey simply aimed at texturing the mesh models and at the extraction of orthophotos of the panels and corbels.

Photo shooting followed the path of laser scanning survey: a first set of photo was taken from the ground and at a later stage a huge amount of photos was taken at a short distance from the scaffolding. Photogrammetric processing was planned to create a single photogrammetric project per each base unit. Photogrammetric projects were all referred to the coordinate system of point clouds and meshes, with the aid of the laser scanning coordinates of specific points well visible in photos (fig. 3). Photos were taken with a mirrorless camera positioned on a tripod; a lighting system made of LED panels, was fixed to a second tripod. The separation between the light source and the camera allowed to reduce the specular reflection produced by the glossy coatings that overlay the paintings.

The final output of the surveying process are the 3D textured models of the base units (fig. 4).
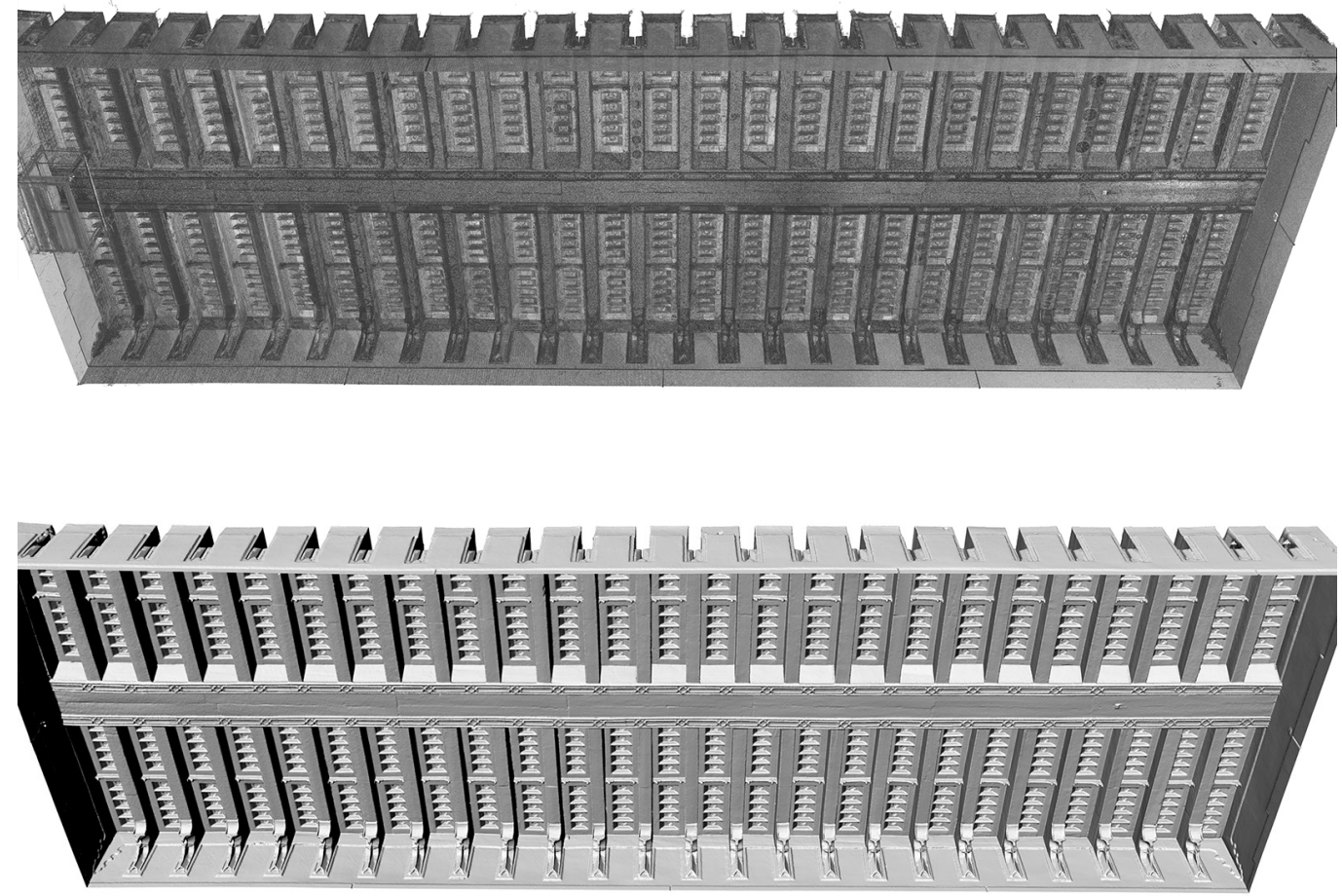

\section{A web-based app for the visualization of the paintings}

In order to allow access and inspection of the 3D textured model to people who are not educated to the use of digital modeling tools, i.e. humanistic scholars, common people or officials accounted for the protection of the ceiling, a web-based application that combines graphic elements and informative databases was implemented.

The main problem in the visualization of the ceiling concerns its considerable size and its complex morphology, characterized by a sequence of vertical, horizontal and oblique panels, and by very articulated corbels.

The visualization of the entire model would be complex; the search of a panel would be a hard task when navigating 48 beams and 50 coffers; these numbers account for the fact that studies conducted so far by art historians have long focused on the problem of the classification of beams and coffers. 
Fig. 3. Points used to refer the photogrammetric

model to the coordinate system of scanned point
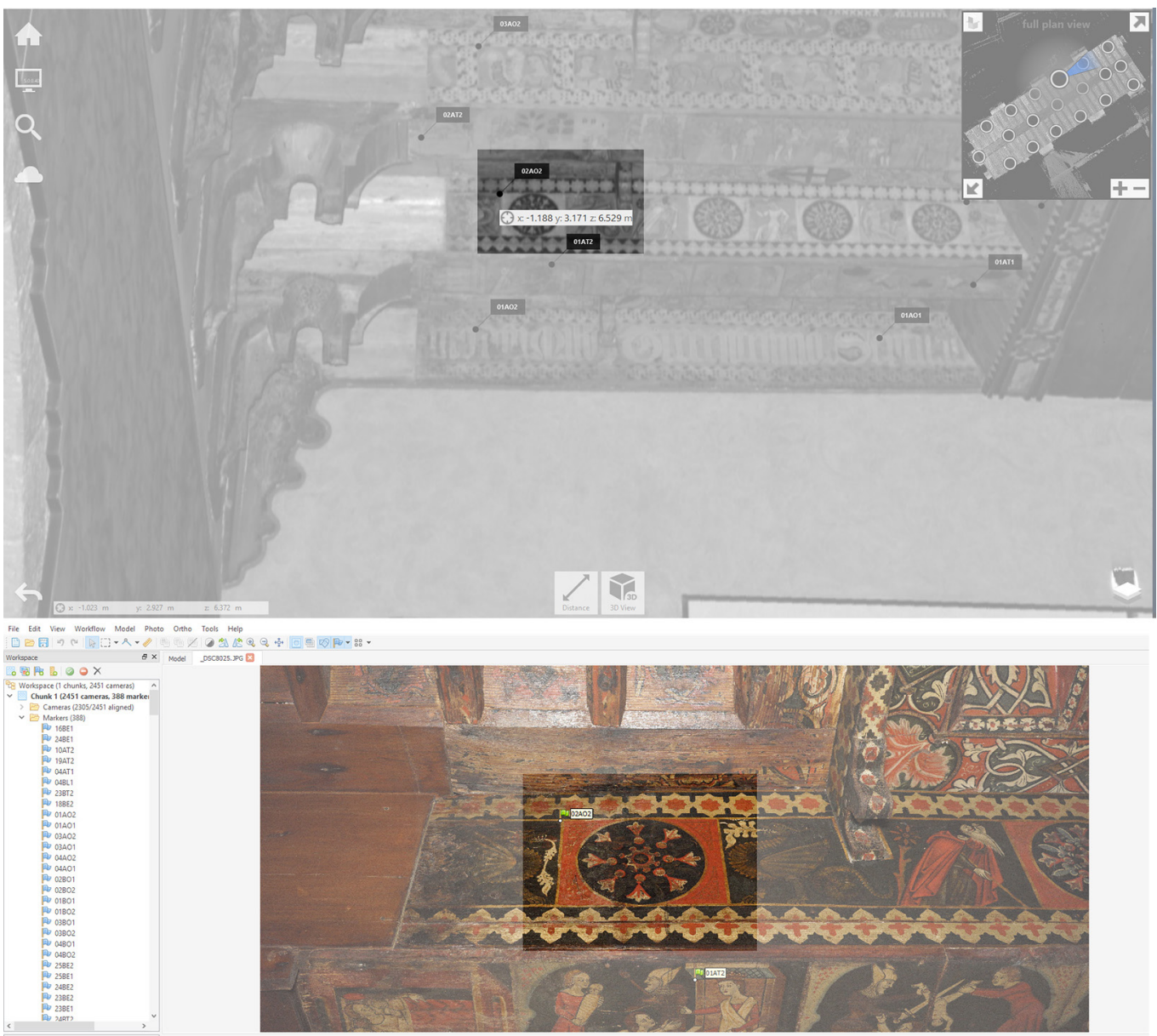

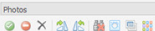

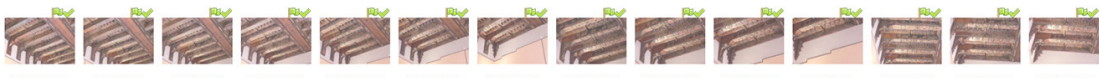

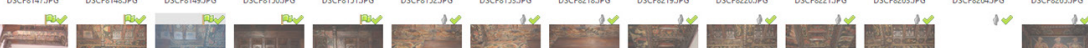

Fig. 4. Photogrammetric texturing of the mesh
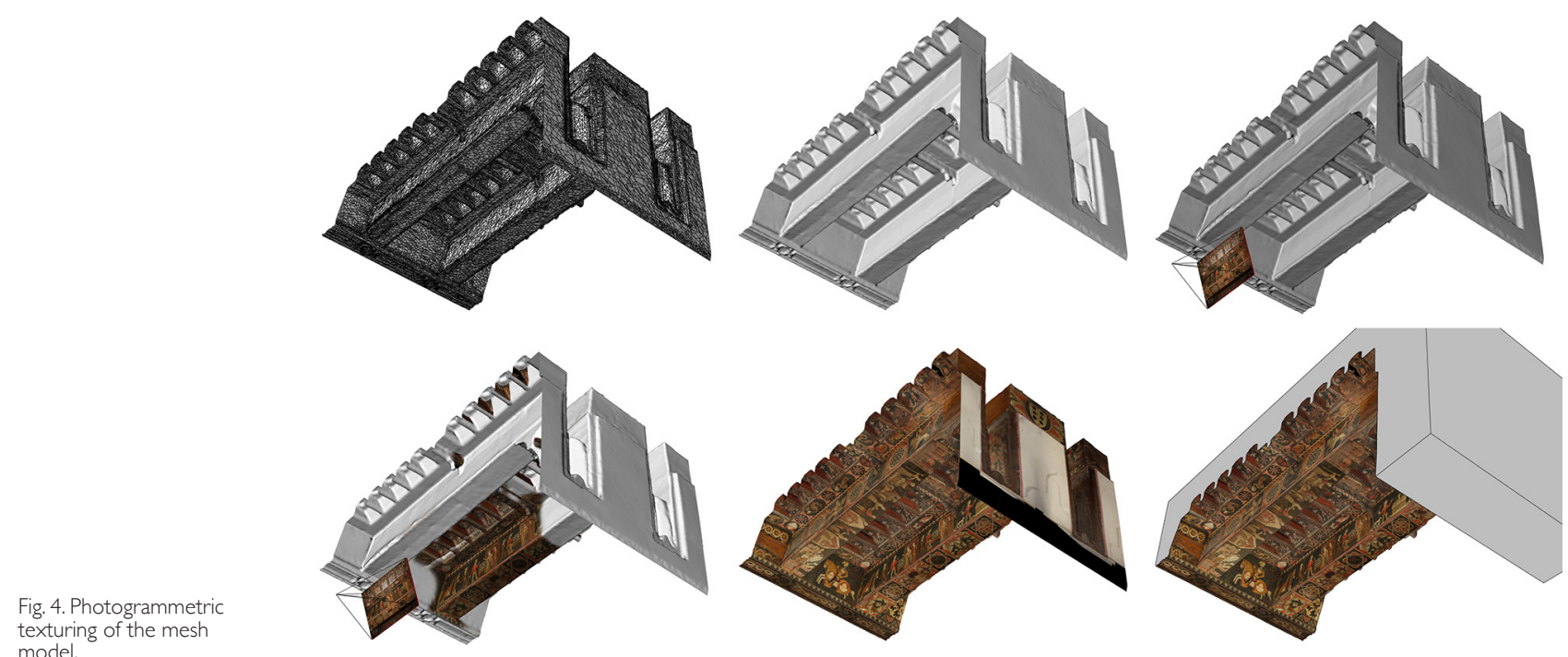
Fig 5. Grayscale orthophoto of the ceiling; the selected base unit is highlighted in RGB mode.
Fig. 6. The image shows the alphanumeric denomination of elements and the overlapping area of two adjacent base units, corresponding to a beam

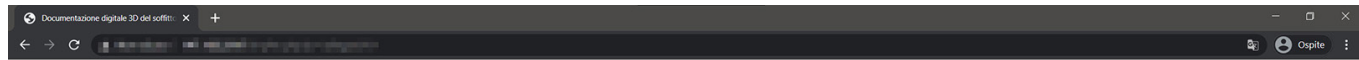

Documentazione generale

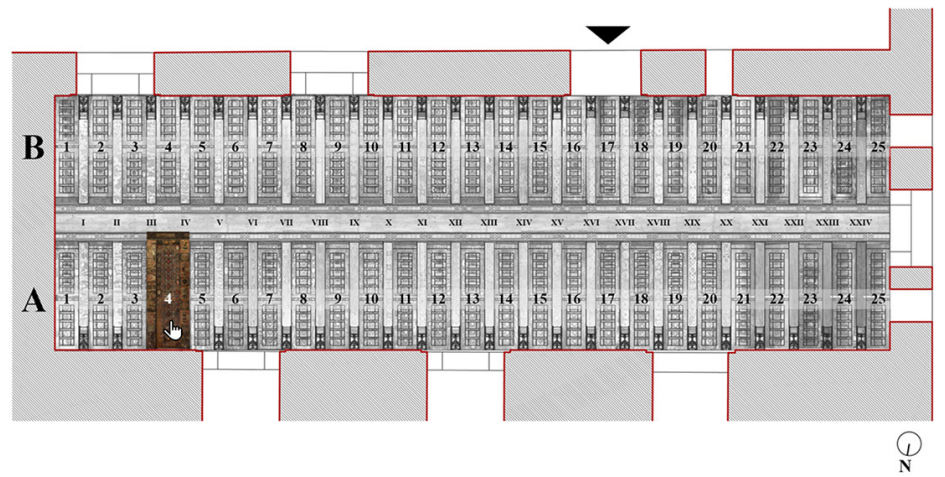

In order to simplify the access and retrieval of elements, the 3D textured model was subdivided into overlapping base units.

Along the transverse direction of the hall, base units are delimited by one of the longitudinal walls and by the trapezoidal element that marks the longitudinal axe of the hall; along the longitudinal direction, base units include two beams and the coffer between them; beams are always displayed entirely, with a horizontal and two vertical faces; the coffers attached to the vertical faces opposed to the area between the beams are partially reported so that the continuity of the ceiling is permanently displayed.

Each base unit overlaps the previous and the following one because it shares with each one beam and a part of a coffer; the units attached to the walls obviously overlap only in one direction. In order to display the limit of each unit, flat surfaces have been used to build an abstract volume, which conceals the actual setup of the extrados of the ceiling, thus giving higher visibility to the paintings.
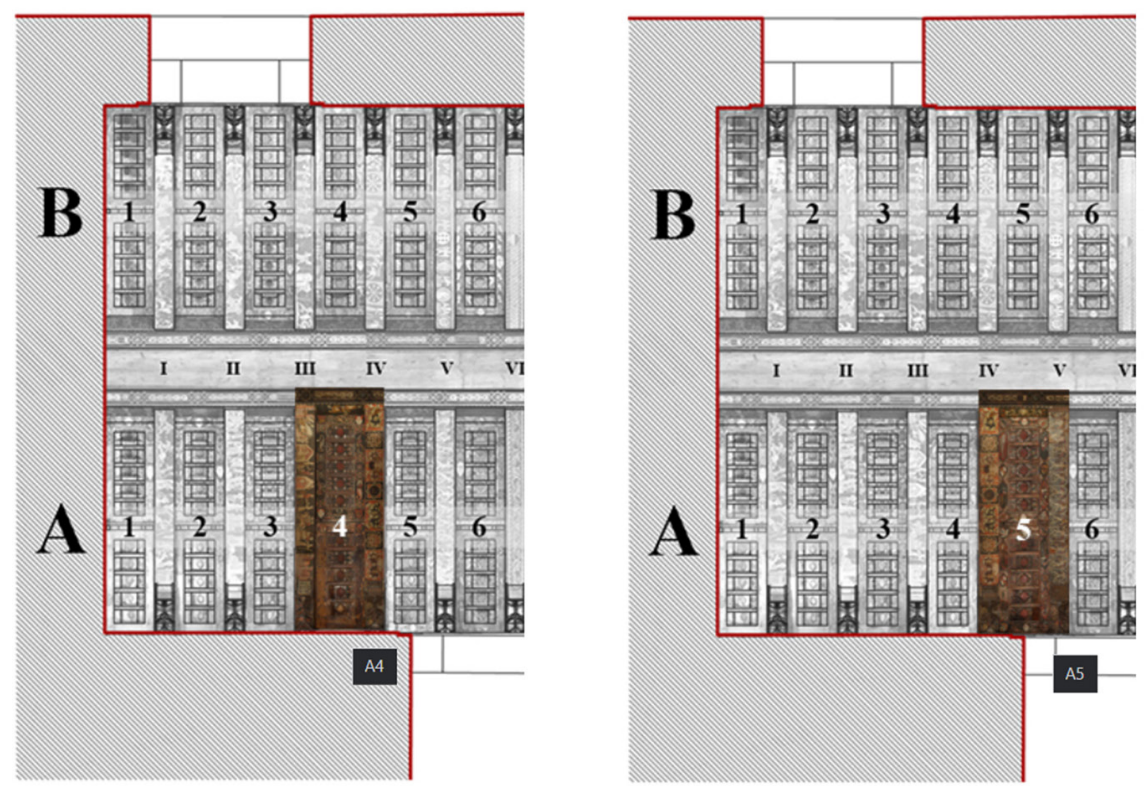


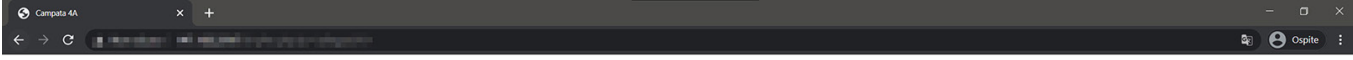

Campata $4 \mathrm{~A}$

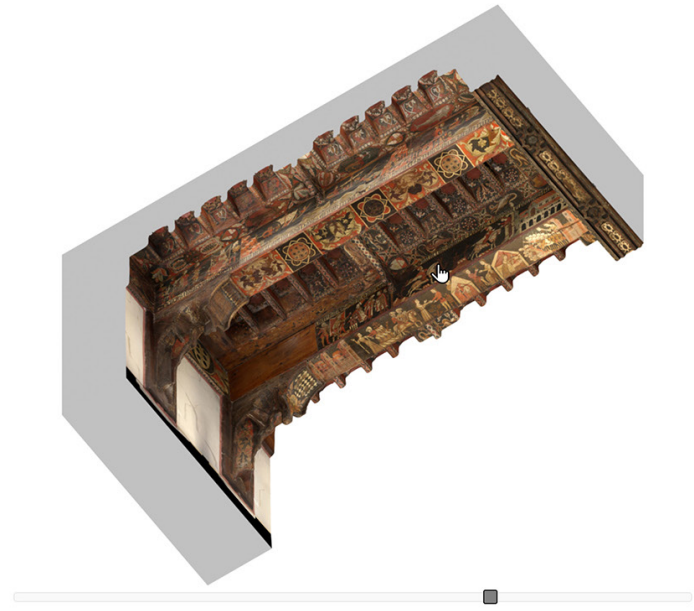

The web-based application has been designed to allow: I) the navigation of the 3D models of the base units; 2) the visualization of the high res orthophotos of the painted panels and corbels; 3) the implementation of a multimedia editable database linked to the orthophotos. In order to simplify the retrieval of base units, the main page of the app, that follows the homepage, displays a gray nadiral orthophoto of the entire ceiling, delimited by the a simplified plan of the hall (fig. 5).

Coffers are named with ordinal numbers, while cardinal numbers mark the 24 beams; letters $\mathrm{A}$ and $\mathrm{B}$ name the parts divided by the element that spans the longitudinal axe of the hall. When the cursor, or the finger in touch systems, points a specific area, the orthophoto of the corresponding base unit becomes colored, thus suggesting the possibility of accessing more contents by clicking on this area (fig. 6).

The click leads to a page where the textured 3D model of the base unit appears in a bottom axonometric projection, with its identification code on the upper right corner.

A slider at the lower end of the page allows, through the left/right movement of the cursor, to rotate the model around z-axis. This way the user can visualize all the wooden painted panels of the base element (fig. 7).

Actually, what appears on screen is not the 3D model, but a sequence of 28 pre-rendered axonometric bottom views. A dedicated javascript app allows to simulate the navigation of the model through the fast sequence of images, controlled by the slider.The use of images that substitute a 3D model make the app lighter and faster, and furthermore compatible with a wide range of platforms and with desktop and mobile devices.

The 28 axonometric views have been rendered with Blender, through the movement, along a semicircular path, of a virtual camera pointed toward the center of the base unit.

Orthophotos are retrieved directly from the 3D model, thus facilitating the identification of the chosen painting and the understanding of its position inside the ceiling and the proximity with other painted elements.

In order to allow the access to orthophoto of one element from the axonometric views, dedicated sensitive areas, whose shape matches the projection of the element in the views where it is displayed, have been created; the shape of these areas has been implemented with a html code. The click on a sensitive area leads to a page where the orthophoto appears (fig. 8) at a high resolution and can be enlarged and shifted to allow the visualization of the smallest details of the paintings; a small pop-up window, at the top left corner of the page, shows the position of the framed detail in an icon of the orthophoto (fig. 9).

A link at the top right of the page leads to the area of the database dedicated to the element displayed in the orthophoto. The access to the database has been designed in two levels: people accounted for the user level can consult and download the documents 

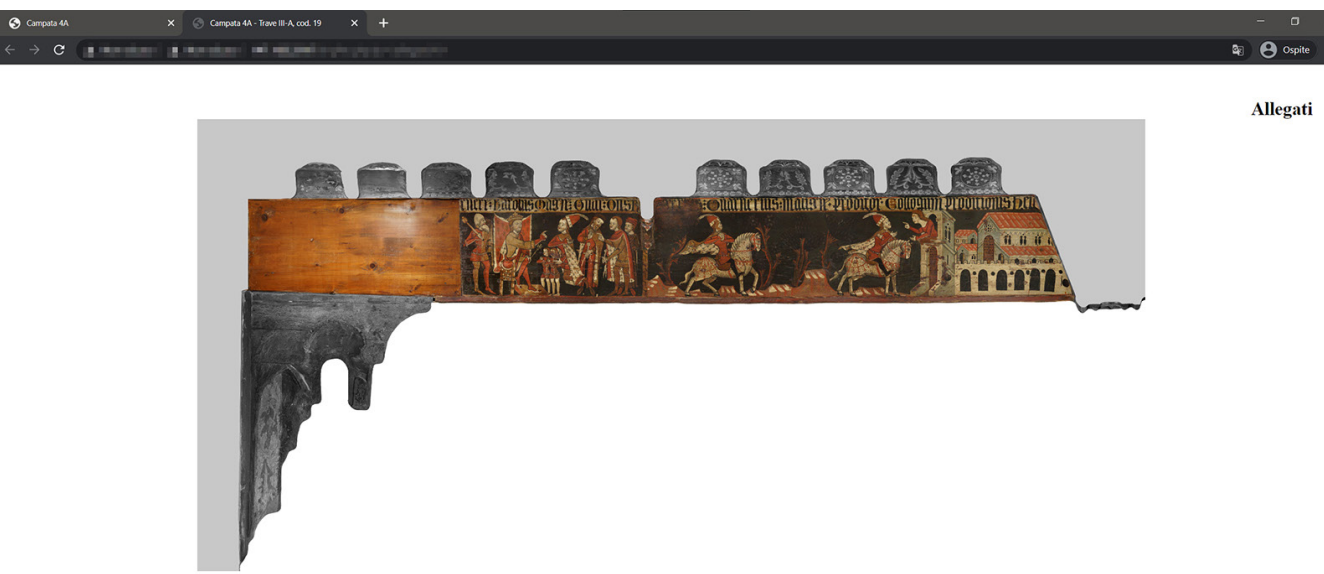

Allegati

Fig. 8. The page of the app dedicated to the orthophoto of the vertical face of a beam
Campata 4A - Trave III-A, cod. 19

Storia di Elena di Narbona in the database, through a file manager based on PHP language; people with higher permission, released by the site manager, can upload new documents, modify existing ones or permanently delete them. The database is stored on a server of the University of Palermo (fig. 10).

\section{Conclusions and outlooks}

The research led to the implementation of a 3D textured model of the painted wooden ceiling that covers the main hall of the Steri of Palermo, headquarter of the rector of the local University, and to the development of a web-based application for the visualization of the model and the access to informative data stored in an editable database.

The application was designed to allow the widest range of users to visualize the 3D layout of the ceiling, the link between the paintings and their support, the proximity between paintings and to facilitate the access to information data.

The experimented workflow could be applied to similar painted ceilings and could support the creation of a digital atlas of painted ceilings in Sicily.

Future experimentation could address the use of 3D textured models in AR applications for in situ visualization, with real-time release of informative content on the subjects depicted in the paintings.
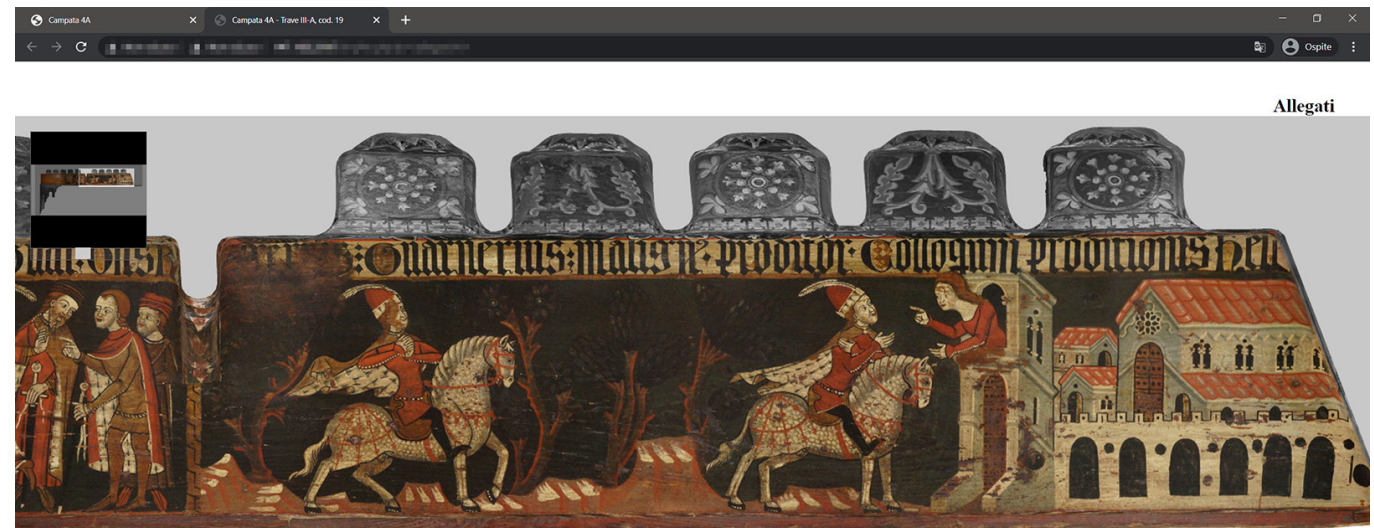

Campata 4A - Trave III-A, cod. 19 Storia di Elena di Narbona 


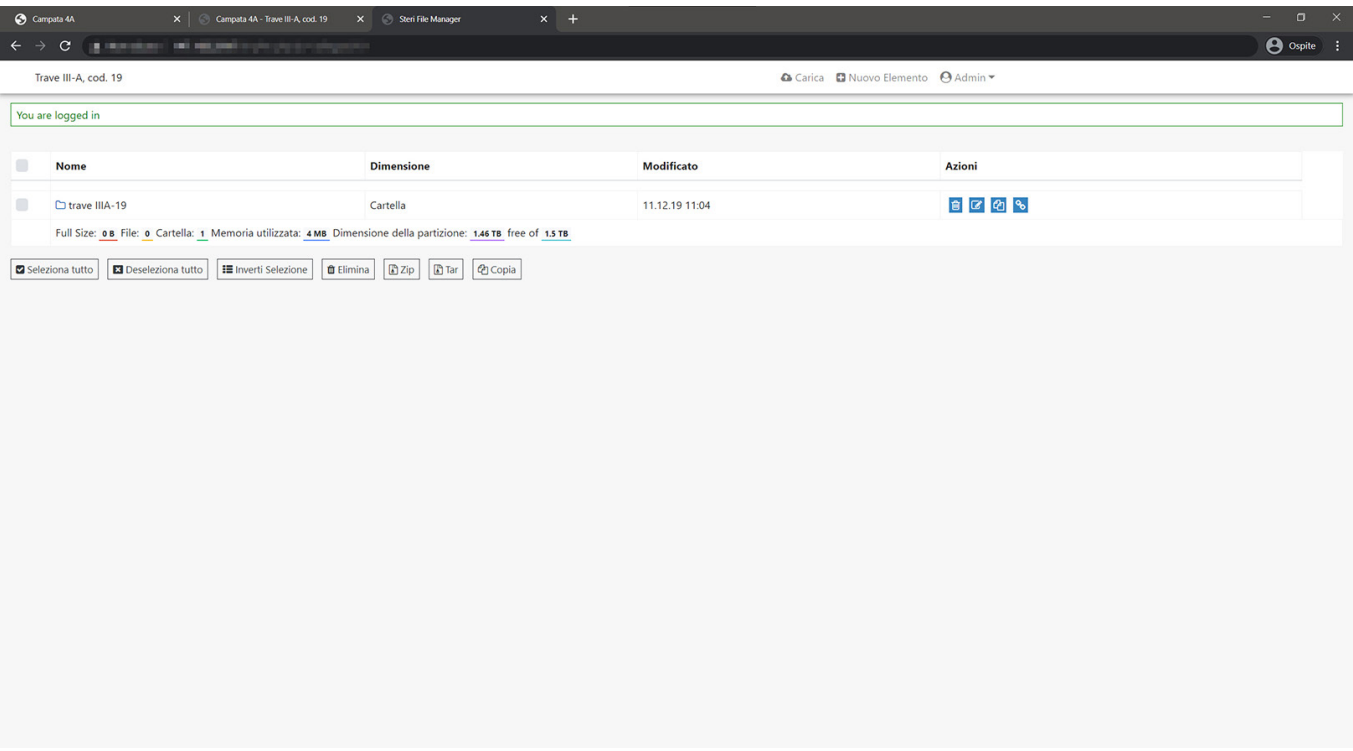

\section{Notes}

[I] Credits: Fabrizio Agnello is the author of the Introduction and the paragraph dedicated to segmentation of 3D models: Mirco Cannella, a PON-AIM Researcher, is the author of the paragraphs dedicated to surveying and to the development of the web-based app.

[2] The mesh of the ceiling has been computed with the freeware package Cloud Compare.

\section{References}

Bologna F. (2002). Il soffitto della Sala Magna allo Steri di Palermo. Palermo: Flaccovio.

Gonizzi Barsanti S., Guidi G., De Luca L. (2017). Segmentation of 3d models for Cultural Heritage Structural Analysis. Some Critical Issues. In ISPRS Annals, vol. IV-2/W2, pp. I I 5- 122.

Guarnieri A., Pirotti F.,Vettore A. (2010). Cultural heritage interactive 3D models on the web: An approach using open source and free software. In Journal of Cultural Heritage, vol. I I, Issue 3, pp. 239-364.

Lanza V. ( 1940). Saggio sui soffitti siciliani dal secolo XII al XVII. Estratto dagli Atti della Regia Accademia di Scienze, lettere ed Arti di Palermo (Serie IV, Vol. I, Parte II), Palermo.

De Luca L., Bussayarat C., Stefani C., Veron P., Florenzano M. (201 I). A semantic based platform for the digital analysis of architectural heritage. In Computers \& Graphics, 20I I, 35(2), pp. 227-24I.

\section{Authors}

Fabrizio Agnello, Università degli Studi di Palermo, fabrizio.agnello@unipa.it

Mirco Cannella, Università degli Studi di Palermo, mirco.cannella@unipa.it

To cite this chapter. Agnello Fabrizio, Cannella Mirco (202I). Sperimentazione di una procedura per la creazione di un atlante digitale per la documentazione dei soffitti lignei dipinti di Sicilia/A Workflow for the Creation of a Digital Atlas for the Documentation of the Painted Wooden Ceilings of Sicily. In Arena A., Arena M., Mediati D., Raffa P. (a cura di). Connettere. Un disegno per annodare e tessere. Linguaggi Distanze Tecnologie Atti del $42^{\circ}$ Convegno Internazionale dei Docenti delle Discipline della Rappresentazione/Connecting. Drawing for weaving relationship. Languages

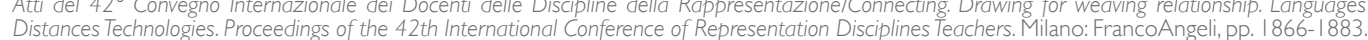

